\title{
Potential of proteolytic enzyme treatment for production of Korean red ginseng extract
}

\author{
Dong Chung Kim ${ }^{1} \cdot$ Tae Jung Lee ${ }^{1} \cdot$ Man-Jin In $^{1}$ \\ 홍삼 추출물의 제조에서 단백질 분해효소의 활용
}

김동청 ${ }^{1}$ - 이태정 ${ }^{1}$ - 인만진 ${ }^{1}$

Received: 10 September 2019 / Accepted: 29 October 2019 / Published Online: 31 December 2019

(C) The Korean Society for Applied Biological Chemistry 2019

\begin{abstract}
In this study, proteolytic enzymatic treatment conditions for Korean red ginseng were examined to increase the extraction yield. Commercially available proteases were screened to obtain high protein and carbohydrate yield. The optimal dosage and reaction time for Alcalase, the chosen protease, were found to be $2.0 \%(\mathrm{w} / \mathrm{w})$ and $1.5 \mathrm{~h}$, respectively. Treatment with optimal conditions of Alcalase increased solid yield, total phenolic content and gensenosides content by $57.6,81.8$, and $33.8 \%$, respectively, over levels in non-treated Korean red ginseng. Antioxidative activities evaluated by free radical scavenging activity, cation radical scavenging activity and reducing power were exactly similar between Alcalase-treated and non-treated extracts.
\end{abstract}

Keywords Antioxidative activity $\cdot$ Gensenosides $\cdot$ Proteolytic enzyme $\cdot$ Red ginseng extract

\section{서 론}

인삼(Panax ginseng C. A. Meyer)은 오랫동안 신진대사를 개 선하고 질병을 예방,치료하기 위하여 사용되고 있는 생약제이며,

Man-Jin In $(\bowtie)$

E-mail: manjin@chungwoon.ac.kr

${ }^{1}$ Department of Chemical Engineering, Chungwoon University, Incheon 22100, Republic of Korea

This is an Open Access article distributed under the terms of the Creative Commons Attribution Non-Commercial License (http://creativecommons org/licenses/by-nc/3.0/) which permits unrestricted non-commercial use, distribution, and reproduction in any medium, provided the original work is properly cited.
인삼에 함유된 주요한 유효성분으로는 진세노사이드를 통칭하 는 인삼 사포닌과 비사포닌계 화합물로 산성 다당체, 폴리아세 틸렌, 알칼로이드, 페놀성 화합물, 펩타이드 등이 보고되어 있 다[1]. 인삼의 약리효능은 대사질환 개선, 간보호, 기억력 개선, 갱년기 질환 및 심혈관 질환 개선, 항산화, 항암, 항염증, 항바 이러스, 면역기능 조절 등이 알려져 있다[2,3]. 인삼은 가공방법 에 따라 모든 인삼의 원료로 원형 그대로 유통되는 수삼, 저장 과 유통을 위하여 수삼을 열풍 건조시킨 백삼과 수증기 등으로 쪄서 익힌 후 건조시킨 홍삼으로 구분된다. 홍삼은 제조과정에 서 가열에 의하여 당과 아미노산 간의 Maillard반응에 의한 갈 변 반응과 같은 화학반응으로 새로운 성분이, 특히 사포닌의 구 조적인 변화로 진세노사이드 $\mathrm{Rg} 2, \mathrm{Rg} 3, \mathrm{Rh} 1, \mathrm{Rh} 2$ 와 같은 홍삼 특유의 사포닌이 생성되며[4,5], 이러한 성분의 변화가 항산화, 항암, 항고혈압 등의 약리 효능 증가에 기여하는 것으로 밝혀 졌다[6,7]. 따라서 인삼 가공품 중 홍삼제품은 건강기능식품시장 에서 수요가 지속적으로 증가하고 있으며, 홍삼제품은 홍삼 추 출물을 주원료로 다른 부원료와 혼합하여 가공하므로 홍삼 추 출물에 대한 관심과 수요도 따라서 높아지고 있다. 홍삼 추출 물은 일반적으로 물 또는 에탄올을 용매로 환류 냉각 추출방법 으로 제조되고 있으나 홍삼 유효성분을 좀더 효과적이며 경제 적으로 추출하기 위한 연구가 진행되고 있다[8,9]. 최근에는 효 소 처리에 의한 추출 수율 향상 및 진세노사이드의 전환[10], 아임계 상태의 물을 용매로 저극성 진세노사이드의 선택적 추 출 및 전환[11], 효소와 초고압 처리에 의한 진세노사이드 $\mathrm{Rd}$ 추출[12] 등이 보고되고 있다. 특히 효소 처리의 경우, 추출 수율 과 항산화 활성 향상 및 생리활성이 우수한 진세노사이드로 전환 을 위하여 $\alpha$-amylase와 glucoamylase [10], cellulase와 cellobiase [12], pectinase[13] 등과 같이 대부분 고분자 탄수화물을 가수 분해하는 효소를 이용하는 연구가 보고되어 있을 뿐 단백질 분 해효소를 홍삼 추출물의 제조에 이용하는 연구는 매우 미미하 다. 인삼에는 고형분 중 조단백이 $12-16 \%$ 로 $60-70 \%$ 의 탄수화 
물 다음으로 다량 함유되어 있으므로[14] 탄수화물뿐만 아니라 단백질의 처리도 추출물 제조에서 중요한 부분이다.

따라서 본 연구에서는 홍삼 추출물의 제조에서 단백질 분해 효소의 영항을 조사하였다. 상업용 단백질 분해효소 중 추출 수 율을 향상시킬 수 있는 효소를 선별하고 최적의 반응조건을 조 사하였다. 또한 단백질 분해효소로 처리한 반응액의 진세노사이 드 함량과 항산화 활성을 분석하여 효소를 처리하지 않은 조건 과 비교함으로써 홍삼 추출물 제조에서 단백질 분해효소의 활 용에 관한 기초적인 자료를 확보하고자 하였다.

\section{재료 및 방법}

\section{재료}

실험에 사용된 홍삼은 건조한 6 년근으로 우신산업(금산, 대한민 국)에서 구입하여 $500 \mu \mathrm{m}$ 이하로 분쇄하여 사용하였으며, 상업 용 단백질 분해효소인 Alcalase, Flavourzyme, Neutrase, Protamex 는 Novozyme (Bagsvaerd, Denmark)의 제품을 구입하였다.

\section{효소 처리}

홍삼 분말을 증류수에 $10 \%(\mathrm{w} / \mathrm{w})$ 로 현탁시킨 후 단백질 분해 효소의 반응 최적 $\mathrm{pH}$ 로 조정한 다음 효소를 홍삼 중량 기준으 로 $1 \%$ 첨가하고 $50{ }^{\circ} \mathrm{C}$ 에서 3 시간 동안 진탕으로 가수분해시켰 다. 효소처리가 끝난 시료는 $100{ }^{\circ} \mathrm{C}$ 에서 5 분간 열처리하여 효 소를 실활시킨 후 원심분리 $\left(3,000 \times g, 4{ }^{\circ} \mathrm{C}, 15\right.$ 분 $)$ 로 상등액을 얻어 분석의 시료로 사용하였다.

\section{단백질과 총탄수화물}

효소 반응액의 단백질 함량은 bovine serum albumin을 표준물 질로 하여 Lowry법으로[15], 총탄수화물 함량은 포도당을 표준 물질로 하여 phenol-sulfuric acid법으로[16] 분석하였다. 단백질 수율(protein yield, PY)과 탄수화물 수율(carbohydrate yield, $\mathrm{CY}$ )를 다음과 같이 계산하여 비교하였다[17].

PY $(\%)=$ 효소 반응액의 총 단백질량/총 홍삼중량 $\times 100$ $\mathrm{CY}(\%)=$ 효소 반응액의 총 탄수화물량/총 홍삼중량 $\times 100$

\section{진세노사이드 함량}

효소 반응액의 진세노사이드 조성과 함량은 $\mathrm{Yu}$ 등의 방법[18] 에 따라 효소 반응액을 Sep-Pak C18에 흡착시킨 후 메탄올로 용출시킨 다음 $0.45 \mu \mathrm{m}$ syringe filter로 여과하여 HPLC를 이용 하여 분석하였다.

\section{항산화 활성}

유리 라디칼 소거활성: DPPH (2,2-diphenyl-1-picryl-hydrazyl) radical의 소거활성은 Blois의 방법[19]으로 측정하였다. 효소 반 응액 $1 \mathrm{~mL}$ 와 $0.15 \mathrm{mM} \mathrm{DPPH}$ 용액 $3 \mathrm{~mL}$ 를 혼합한 후 실온에 서 30 분간 반응시킨 다음 $525 \mathrm{~nm}$ 에서의 흡광도를 측정하여 대 조구와 비교하였다.

양이온 라디칼 소거활성: 2,2'-azinobis-(3-ethyl-benzothiazoline)sulfonic acid (ABTS) 라디칼의 소거활성은 $\operatorname{Re}$ 등의 방법[20]으
로 측정하였다. ABTS 용액(ABTS $7.4 \mathrm{mM}$, potassium persulfate $2.6 \mathrm{mM}$ )을 15 시간 동안 암소에서 반응시켜 $\mathrm{ABTS}$ 양이온 라디 칼을 형성시킨 후 $414 \mathrm{~nm}$ 에서 흡광도가 1.5 가 되도록 $\mathrm{ABTS}$ 용액을 희석하였다. 효소 반응액 $0.1 \mathrm{~mL}$ 에 ABTS 라디칼 용액 $3 \mathrm{~mL}$ 를 혼합한 후 실온에서 1.5 시간 반응시킨 다음 $414 \mathrm{~nm}$ 에 서 흡광도를 측정하여 양이온 라디칼 소거활성을 계산하였다.

환원력: $\mathrm{Fe}^{3+}$ 이온을 환원시키는 능력을 $\mathrm{Oyaizu}$ 의 방법[21]으로 측정하였다. 인산 완충액 $(0.2 \mathrm{M}, \mathrm{pH}$ 6.6) $2.5 \mathrm{~mL}$ 에 효소 반응액 $1 \mathrm{~mL}$ 를 넣고 $1 \%$ potassium ferricyanide (III) 용액을 $2.5 \mathrm{~mL}$ 첨가하여 $50{ }^{\circ} \mathrm{C}$ 에서 20 분간 반응시킨 후 $10 \%$ trichloroacetic acid 용액을 $2.5 \mathrm{~mL}$ 추가한 다음 원심분리 $(2,500 \times \mathrm{g}, 5$ 분 $)$ 하였다. 상등액 $2.5 \mathrm{~mL}$ 와 증류수 $2.5 \mathrm{~mL}$ 를 혼합하고 $0.1 \%$ ferric chloride 용액 $0.5 \mathrm{~mL}$ 와 반응시킨 후 $700 \mathrm{~nm}$ 에서 흡광도를 측 정하여 환원력으로 나타내었다.

\section{총페놀 함량}

효소 반응액이 총페놀 함량은 Folin과 Denis의 방법[22]으로 측 정하였다. 효소 반응액 $1 \mathrm{~mL}$ 에 Folin-Ciocalteu 시약 $2 \mathrm{~mL}$ 를 넣 은 후 실온에서 3 분 동안 반응시킨 다음 $2 \mathrm{~mL}$ 의 $10 \%$ sodium carbonate 용액을 넣어 1시간 정치시키고 $760 \mathrm{~nm}$ 에서의 흡광도 를 측정하여 총페놀 화합물의 함량을 계산하였다. 총페놀 화합 물의 함량은 gallic acid를 표준물질로 하여 환산하였다.

\section{통계분석}

실험 결과는 평균과 표준편차로 나타내었고 SPSS 12.0 (SPSS Inc, Chicago, IL, USA)을 사용하여 t-test를 통하여 시료간 유 의성 $(p<0.05)$ 을 검정하였다.

\section{결과 및 고찰}

\section{효소선별 및 효소처리 조건}

홍삼 추출물의 추출 효율을 향상시킬 수 있는 단백질 분해효소 를 선별하기 위하여 $10 \%$ 홍삼 현탁액에 홍삼 중량의 $1 \%$ 로 효 소를 처리한 후 효소 반응액의 단백질과 탄수화물 함량을 분석 하여 단백질 수율(protein yield)과 탄수화물 수율(carbohydrate yield)로 비교하였다. 그 결과(Table 1), 단백질 수율은 모든 효 소 처리구에서 대조구보다 통계적으로 유의하게 증가하였으며, Alcalase를 처리한 조건에서 $6.7 \%$ 로 대조구의 $4.1 \%$ 보다 $60 \%$ 이상 향상되어 가장 높았다. 탄수화물 수율도 단백질 수율과 매 우 유사한 경향으로 Alcalase가 45.2\%로 대조구의 $29.0 \%$ 보다 $50 \%$ 이상 향상된 결과를 보였다. 그러므로 홍삼 추출물 제조를 위한 단백질 분해효소로는 Alcalase가 효과적일 것으로 판단된 다. 이러한 결과는 단백질 분해효소에 의하여 식물세포벽에 존 재하는 peptidoglycan의 단백질 부분이 가수분해되어 단백질과 다당류의 용해도가 증가한다는 보고[23]와 홍삼박의 가용화를 위한 효소처리[17]와도 매우 유사하였다.

Alcalase의 최적 처리농도를 결정하기 위하여 홍삼 현탁액에 홍삼 중량의 $0.5-4.0 \%$ 로 효소를 첨가하여 $50{ }^{\circ} \mathrm{C}$ 에서 3 시간 반 응시키고 단백질과 탄수화물 수율의 변화를 조사하였다. 단백질 과 탄수화물 수율은 효소 처리 농도 $2.0 \%$ 까지 효소 사용량에 
Table 1 Effects of various proteolytic enzyme treatments on hydrolysis of red ginseng

\begin{tabular}{lcc}
\hline \hline \multicolumn{1}{c}{ Enzymes } & Protein yield (\%) & Carbohydrate yield (\%) \\
\hline Alcalase & $6.7 \pm 0.28^{1) *}$ & $45.2 \pm 1.38^{*}$ \\
Flavourzyme & $4.6 \pm 0.03^{*}$ & $44.4 \pm 0.32^{*}$ \\
Neutrase & $4.8 \pm 0.05^{*}$ & $30.1 \pm 2.76$ \\
Protamex & $6.2 \pm 0.01^{*}$ & $31.1 \pm 0.53^{*}$ \\
Control & $4.1 \pm 0.17$ & $29.0 \pm 0.57$ \\
\hline
\end{tabular}

${ }^{1)}$ Values are means $\pm \mathrm{SD}$

${ }^{2)}$ Data were statistically different from the value of control group $(* p<0.05)$
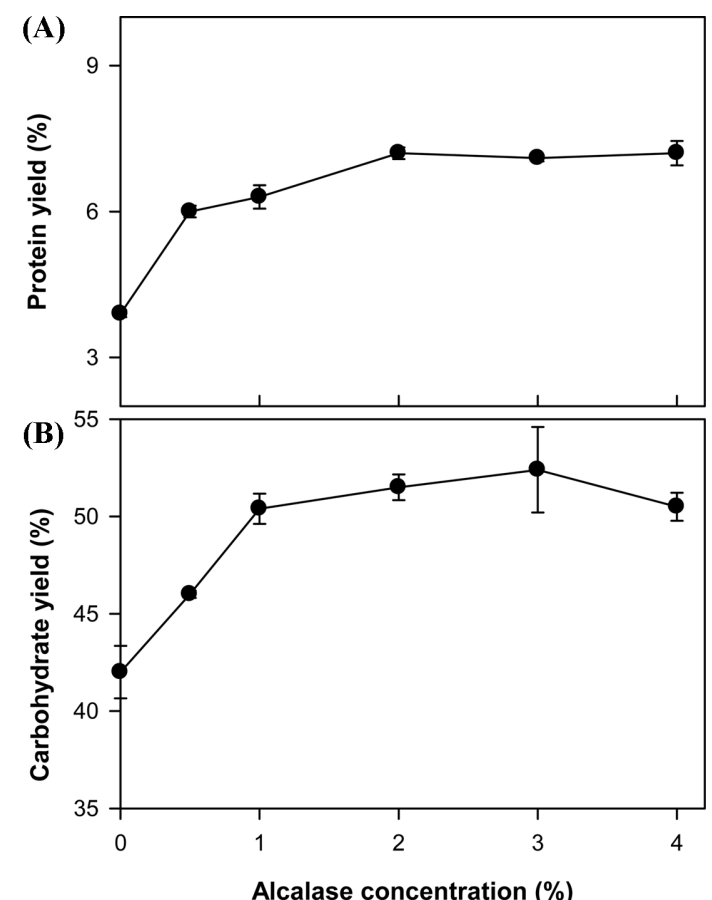

Fig. 1 Effects of Alcalase dosage on protein yield (panel A) and carbohydrate yield (panel B). Reaction conditions: substrate, $10 \%$ red ginseng suspension; temperature, $50{ }^{\circ} \mathrm{C} ; \mathrm{pH}, 8.0$; reaction time, $3 \mathrm{~h}$. Data were means and SD of triplicate measurements

비례하여 급격하게 증가하였으며 그 이상의 농도에서는 수율의 증가는 매우 미미하였다(Fig. 1). Alcalase $2.0 \%$ 의 결과를 대조 구와 비교하면 단백질 수율은 $3.9 \%$ 에서 $7.2 \%$ 로, 탄수화물 수 율은 $42.0 \%$ 에서 $51.5 \%$ 로 증가하였다. 따라서 Alcalase 사용량 은 홍삼 중량의 $2 \%$ 가 적합하였으며, 이 조건에서 반응시간에 따른 단백질과 탄수화물 수율의 변화를 조사하였다. 단백질과 탄수화물 수율은 반응 30 분만에 빠르게 1.5 시간까지 완만하게 증가하였으며 그 이후 4시간까지 변화가 미미하였다(Fig. 2) Alcalase로 1.5 시간 반응시키면 단백질 수율은 $7.1 \%$, 탄수화물 수율은 $46.3 \%$ 까지 증가하여 최적 가수분해시간은 1.5 시간으로 설정하였다. 인삼 추출물의 추출수율이 pectinase $>$ cellulase $>\alpha$ amylase $>$ protease 순으로 향상된다는 결과[13]와 탄수화물 분 해효소와 단백질 분해효소의 동시처리가 홍삼박의 가용화에 효 과적이라는 보고[17]을 고려하면 본 연구에서도 탄수화물 분해

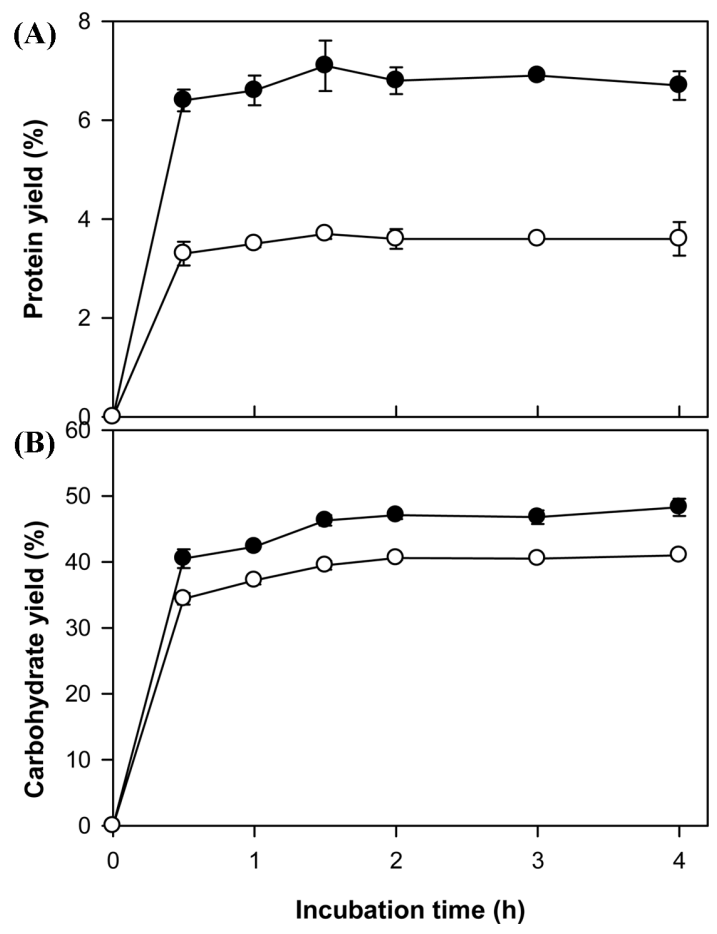

Fig. 2 Effects of reaction time on protein yield (panel A) and carbohydrate yield (panel B). Reaction conditions: substrate, 10\% red ginseng suspension; enzyme dosage, $2 \%$; temperature, $50{ }^{\circ} \mathrm{C} ; \mathrm{pH}, 8.0$. Data were means and SD of triplicate measurements

효소의 병용효과를 추가로 검토하는 것이 필요하다.

\section{총페놀 함량 및 항산화 활성}

홍삼분말 $10 \%(\mathrm{w} / \mathrm{w})$ 에 Alcalase의 최적 반응조건으로 처리한 반 응액의 고형분 기준 수율은 $71.1 \%$ 로 대조구의 $45.1 \%$ 보다 $50 \%$ 이상 증가하여 통계적으로도 유의한 결과를 보였다(Table 2). 이 는 효소처리로 홍삼의 단백질과 탄수화물의 가용화에 기인하는 것이며, 인삼에 Bacillus polymyxa 기원의 protease를 처리한 경 우 추출물 수율이 $34.3 \%$ 라는 보고[13]보다 우수하였다. 통상적 인 열수 추출에서 1 회 추출의 수율은 $48.0 \%$ 이며 4 회 반복추출 은 $71.0 \%$ 라는 결과[24]와 비교하면 본 연구가 매우 효율적이었 다. 또한 총페놀 화합물 함량을 측정한 결과, 고형분 수율의 향 상과 동일하게 효소처리에 의하여 총페놀 함량도 대조구의 $0.44 \%$ 에서 $0.80 \%$ 로 크게 증가하였고 통계적으로도 유의하였다 (Table 2). 식물 세포벽을 분해하는 효소의 사용으로 폴리페놀 화합물의 추출이 향상[25]되지만 홍삼의 경우에는 탄수화물 분 해효소에 의하여 폴리페놀 함량이 유의적으로 증가하지 않는다 는 보고[26,27]도 있다. 그러나 본 연구의 결과는 인삼에 Bacillus polymyxa 기원의 protease를 처리한 경우 총 페놀함량 이 $0.69 \%$ (대조구 $0.34 \%$ )라는 결과[13]와 매우 유사하였다.

Alcalase로 처리한 홍삼 분해물의 항산화 활성을 유리 및 양 이온 라디칼 소거활성과 $\mathrm{Fe}^{3+}$ 이온을 환원력으로 측정하여 대 조군과 비교하였다(Fig. 3). 고형분 농도에 따라 효소 분해물과 대조군의 항산화 활성이 매우 유사한 경향을 보였으며, 이는 효 소처리로 고형분 수율이 증가됨과 동시에 총페놀 화합물의 수 
Table 2 Quality characteristics of Alcalase-treated and control extract from Korean red ginseng

\begin{tabular}{|c|c|c|c|c|}
\hline & & & $\begin{array}{l}\text { Alcalase- } \\
\text { treated }\end{array}$ & Control \\
\hline \multicolumn{2}{|c|}{ Extract yield (\%) } & & \multicolumn{2}{|c|}{$71.1 \pm 2.7^{1) *} 45.1 \pm 0.1$} \\
\hline \multicolumn{2}{|c|}{ Total phenol (\%) } & & \multicolumn{2}{|c|}{$0.80 \pm 0.016 * 0.44 \pm 0.025$} \\
\hline \multirow{15}{*}{$\begin{array}{l}\text { Ginsenosides } \\
(\mathrm{mg} / \mathrm{g})\end{array}$} & \multirow[t]{6}{*}{ Protopanaxatriol } & Rg1 & 0.27 & 0.24 \\
\hline & & $\operatorname{Re}$ & 0.28 & 0.24 \\
\hline & & $\mathrm{Rf}$ & 0.08 & 0.06 \\
\hline & & Rh1 $(\mathrm{S}+\mathrm{R})$ & 0.03 & 0.02 \\
\hline & & $\operatorname{Rg} 2(\mathrm{~S}+\mathrm{R})$ & 0.03 & 0.02 \\
\hline & & Sub-total & 0.69 & 0.58 \\
\hline & \multirow{8}{*}{ Protopanaxadiol } & $\mathrm{Rb} 1$ & 0.57 & 0.41 \\
\hline & & $\mathrm{Rb} 2$ & 0.24 & 0.17 \\
\hline & & $\mathrm{Rc}$ & 0.23 & 0.17 \\
\hline & & $\mathrm{Rb} 3$ & 0.04 & 0.03 \\
\hline & & $\mathrm{Rd}$ & 0.08 & 0.05 \\
\hline & & $\operatorname{Rg} 3(\mathrm{~S}+\mathrm{R})$ & 0.03 & 0.01 \\
\hline & & $\mathrm{F} 2$ & 0.10 & 0.06 \\
\hline & & Sub-total & 1.29 & 0.90 \\
\hline & Total & & 1.98 & 1.48 \\
\hline
\end{tabular}

${ }^{1)}$ Values are means $\pm \mathrm{SD}$

${ }^{2)}$ Data were statistically different from the value of control group $(* p<0.05)$

율도 증가하였기 때문이다. 다만 $10 \mathrm{mg} / \mathrm{mL}$ 이상의 농도에서 효 소 분해물보다 대조군의 유리 라디칼 소거활성이 다소 우수한 것으로 조사된 것은(Fig $3 \mathrm{~A})$, 인삼의 효소처리로 총 페놀의 함 량이 pectinase $>\alpha$-amylase $>$ protease $>$ cellulase의 순이었으나 $10 \mathrm{mg} / \mathrm{mL}$ 에서 유리 라디칼 소거활성은 pectinase > cellulase $>$ protease $>\alpha$-amylase 순으로 총페놀 함량의 순서와 상이함[13] 과 인삼에 함유된 페놀성 성분마다 tyrosinase 활성 억제 활성 의 차이가 존재함[28]을 고려하면 반응성이 상이한 여러가지 페 놀성 화합물의 작용에 의한 것으로 사료된다.

\section{진세노사이드 함량}

홍삼분말 $10 \%(\mathrm{w} / \mathrm{w})$ 에 Alcalase를 홍상 중량의 $2 \%$ 로 첨가하고 1.5 시간 반응시킨 효소 반응액의 진세노사이드 함량과 조성을 대 조구와 비교하였다(Table 2). 효소처리에 의하여 Protopanaxatriol 진세노사이드는 $0.58 \mathrm{mg} / \mathrm{g}$ 에서 $0.69 \mathrm{mg} / \mathrm{g}$ 으로, protopanaxadiol 진세노사이드는 $0.90 \mathrm{mg} / \mathrm{g}$ 에서 $1.29 \mathrm{mg} / \mathrm{g}$ 으로 증가하여 protopanaxadiol계의 증가 정도가 높았으며, 총 진세노사이드 함량은 대조구의 $1.48 \mathrm{mg} / \mathrm{g}$ 에서 $1.98 \mathrm{mg} / \mathrm{g}$ 으로 $30 \%$ 이상 증가하였다. 또한 $\mathrm{Rb} 1$ 과 $\mathrm{Rg} 1$ 이 중요한 진세노사이드로 ginsenoside $\beta$ glucosidase를 이용한 홍삼 추출물[29]에서와 동일한 경향이었다. 홍삼 추출물의 총 탄수화물 함량 증가로 나타나는 홍삼 탄수화 물의 가수분해는 진세노사이드와 같은 유효성분의 추출을 향상 시킨다는 기존의 보고[26,30]와 같이 본 연구에서도 단백질 분 해효소의 처리는 단백질뿐만 아니라 탄수화물의 가용화를 증가 시켜(탄수화물 수율 증가로 나타남) 진세노사이드의 추출 향상 에 기여하는 것으로 판단된다. 따라서 본 연구 결과는 단백질

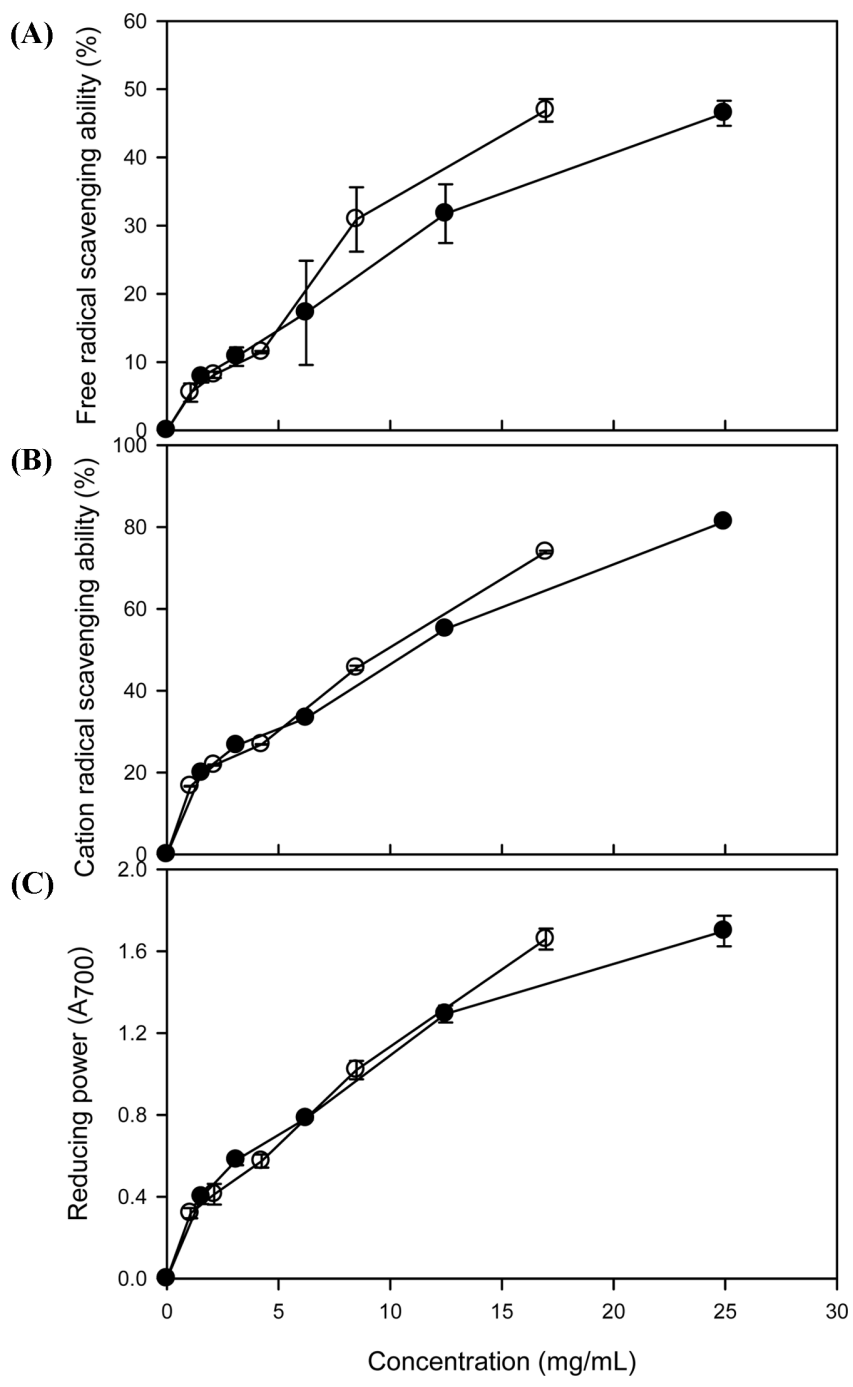

Fig. 3 Antioxidative activities of Alcalase-treated $(\boldsymbol{O})$ and control $(\bigcirc)$ extract from Korean red ginseng. Panel A, free radical scavenging activity; panel $\mathrm{B}$, cation radical scavenging activity; panel $\mathrm{C}, \mathrm{Fe}^{3+}$ reducing power. Data were means and $\mathrm{SD}$ of triplicate measurements

분해효소의 사용이 홍삼 추출물의 수율, 총페놀 화합물 및 진 세노사이드 추출을 향상시킬 수 있음을 제시하므로 효율적인 홍 삼 추출물 제조를 위하여 물이나 주정을 이용한 기존의 추출 공정뿐만 아니라 온도와 압력을 이용한 새로운 추출 공정 $[11,12]$ 에서도 본 연구의 결과를 활용할 수 있을 것으로 사료된다.

\section{초 록}

본 연구에서는 홍삼 추출물 제조과정에서 추출 수율을 향상시 킬 수 있는 효소를 선별하고 최적의 반응조건을 조사하였다. 상 업용 단백질 분해효소 중 Alcalase가 단백질과 탄수화물 수율 향상에 효과적이었으며, 효소 사용량은 홍삼 중량의 $2 \%$, 반응 시간은 1.5 시간이 적당하였다. 최적의 반응조건으로 홍삼을 Alcalase로 처리한 결과 대조구보다 고형분 수율은 $45.1 \%$ 에서 
$71.1 \%$ 로 $50 \%$ 이상, 총페놀 함량은 $0.44 \%$ 에서 $0.80 \%$ 로 $80 \%$ 이상 증가하였으며, 항산화 활성은 대조군과 매우 유사하였다. 또한 진세노사이드 함량은 대조구의 $1.48 \mathrm{mg} / \mathrm{g}$ 에서 $1.98 \mathrm{mg} / \mathrm{g}$ 으 로 $30 \%$ 이상 증가하였다.

Keywords 단백질 분해효소·진세노사이드 - 항산화 활성·홍 삼 추출물

감사의 글 본 연구는 2015 년 중소기업청의 산학연협력기술개발사업 (C0353077)의 지원을 받아 수행하였습니다.

\section{References}

1. Anele AS, Wu JA, Yuan CS (1999) Ginseng pharmacology: Multiple constituents and multiple actions. Biochem Pharmacol 58: 1685-1693

2. Nam KY (2002) Clinical applications and efficacy of Korean ginseng. J Ginseng Res 26: 111-131

3. Kwak YS, Park JD, Yang JW (2003) Present and its prospect of red ginseng efficacy research. Food Ind Nutr 8: 30-37

4. Park JD (1996) Recent studies on the chemical constituents of Korean ginseng (Panax ginseng C. A. Meyer). Korean J Ginseng Sci 20: 389 415

5. Kwak YS, Choi KH, Kyung JS, Won JY, Rhee MH, Lee JG, Hwang MS, Kim SC, Park CK, Song KB, Han GH (2008) Effects of high temperature heating on the some physicochemical properties of Korean red ginseng (Panax ginseng C. A. Meyer) water extract. J Ginseng Res 32; 120-126

6. Keum YS, Park KK, Lee JM, Chun KS, Park JH, Lee SK, Kwon HJ, Surh YJ (2000) Antioxidant and anti-tumor promoting activities of the methanol extract of heat-processed ginseng. Cancer Lett 150: 41-48

7. Lee KH, Bae IY, Park SI, Park JD, Lee GH (2016) Antihypertensive effect of Korean red ginseng by enrichment of ginsenoside $\operatorname{Rg} 3$ and arginine-fructose. J Ginseng Res 40: 237-244

8. Lee SH, Kang JI, Lee SY (2008) Saponin composition and physicochemical properties of Korean red ginseng extract as affected by extracting conditions. J Korean Soc Food Sci Nutr 37: 256-260

9. Li XG, Han JS, Park YJ, Kang SJ, Kim JS, Nam KY, Lee KT, Choi JE (2009) Extraction conditions for promoting ginsenoside contents and taste of red ginseng water extract. Korean J Crop Sci 54: 287-293

10. Kim BG, Choi SY, Suh HJ, Park HJ (2011) Bitterness reduction and enzymatic transformation of ginsenosides from Korean red ginseng (Panax ginseng) extract. J Food Biochem 35: 1267-1282

11. Lee JM, Ko MJ, Chung MS (2015) Physicochemical properties and composition of ginsenosides in red ginseng extract as revealed by subcritical water extraction. Korean J Food Sci Technol 47: 757-764

12. Palaniyandi SA, Damodharan K, Lee KW, Yang SH, Suh JW (2015) Enrichment of ginsenoside $\mathrm{Rd}$ in Panax ginseng extract with combination of enzyme treatment and high hydrostatic pressure. Biotechnol Biopro Eng 20: 608-613

13. Kim YC, Cho CW, Rhee YK, Yoo KM, Rho J (2007) Antioxidant activity of ginseng extracts prepared by enzyme and heat treatment. J Korean Soc Food Sci Nutr 36: 1482-1485

14. Park CK, Jeon BS, Yang JW (2003) The chemical components of Korean ginseng. Food Ind Nutr 8: 10-23

15. Lowry OH, Rosebrough NJ, Farr AL, Randall RJ (1951) Protein measurement with the Folin phenol reagent. J Biol Chem 193: 265-275

16. Dubois M, Gilles KA, Hamilton JK, Rebers PA, Smith F (1956) Colorimetric method for determination of sugars and related substances. Anal Chem 28: 350-356

17. Kim DC, In MJ (2010) Production of hydrolyzed red ginseng residue and its application to lactic acid bacteria cultivation. J Ginseng Res 34 : 321-326

18. Yu JY, Jin YR, Lee JJ, Chung JH, Noh JY, You SH, Kim KN, Im JH, Lee JH, Seo JM, Han HJ, Lim Y, Park WS, Kim TJ, Shin KS, Wee JJ, Park JD, Yun YP (2006) Antiplatelet and antithrombotic activities of Korean red ginseng. Arch Pharm Res 29: 898-903

19. Blois MS (1958) Antioxidant determination by the use of a stable free radical. Nature 181: 1199-1200

20. Re R, Pellegrini N, Proteggente A, Pannala A, Yang M, Rice-Evans C (1999) Antioxidant activity applying an improved ABTS radical cation decolorization assay. Free Radical Biol Med 26: 1231-1237

21. Oyaizu M (1985) Studies on products of browning reaction: antioxidant activities of products of browning reaction prepared from glucosamine. Jap J Nutr 44: 307-315

22. Folin O, Denis W (1912) On phosphotungstic-phosphomolybdic compounds as color reagents. J Biol Chem 12: 239-243

23. Chae HJ, Han MS, In MJ (2004) Study on utilization of vegetable byproduct from food processing by enzyme treatment. J Korean Soc Appl Biol Chem 47: 146-148

24. Yoo G, Lee SD, In MJ, Hwang WI, Lee KS, Lee ES, Kim DC, Chae HJ (2009) An alternative sequential extraction process for maximal utilization of bioactive components from Korean red ginseng. Korean J Chem Eng 26: 1094-1097

25. Landbo AK, Meyer AS (2001) Enzyme-assisted extraction of antioxidative phenols from black currant juice press residues (Ribes nigrum). J Agric Food Chem 49: 3169-3177

26. Choi HS, Kim SY, Park Y, Jung EY, Suh HJ (2014) Enzymatic transformation of ginsenosides in Korean red ginseng (Panax ginseng Meyer) extract prepared by Spezyme and Optidex. J Ginseng Res 38: 264-269

27. Kim HJ, Yang SA, Im NK, Jhee KH, Lee IS (2008) Antioxidant effect of oil containing cellulase-treated red ginseng. J Life Sci 18: 323-328

28. Hwang EY, Kong YH, Lee YC, Kim YC, Yoo KM, Jo YO, Choi SY (2006) Comparison of phenolic compounds contents between white and res ginseng and their inhibitory effect on melanin biosynthesis. J Ginseng Res 30: 82-87

29. Hwang E, Sun ZW, Lee TH, Shin HS, Park SY, Lee DG, Cho BG, Sohn H, Kwon OW, Kim SY, Yi TH (2013) Enzyme-processed Korean red ginseng extracts protects against skin damage induced by UVB irradiation in hairless mice. J Ginseng Res 37: 425-434

30. Ko SR, Suzuki Y, Suzuki K, Choi KJ, Cho BG (2007) Marked production of ginsenoside Rd, F2, Rg3, and compound $\mathrm{K}$ by enzymatic method. Chem Pharm Bull 55: 1522-1527 